\title{
Nonlinear Prediction Models for Estimation of Pre-weaning Body Weight of Pigs using Morphometric Traits
}

Santanu Banik, Soumen Naskar, Keshab Barman, Pranab Jyoti Das, Sunil Kumar, Swaraj Rajkhowa

10.18805/IJAR.B-4174

\begin{abstract}
Background: In the present study, a set of non-linear prediction equation was developed using records of body measurement traits, namely heart girth, punch girth, height at shoulder, height at back, height at fore leg, height at back leg and body length of pigs. Repeated measurement of traits at birth, $15 \mathrm{~d}, 30 \mathrm{~d}$ and weaning (42 d) of 394 piglets were used.

Methods: The regression of body weight on body measurement traits showed non-linear relationship based on equation, $Y=a X^{b}$. Correlation of heart girth with body weight $\left(r^{2}=0.968\right.$ for male and 0.969 for females; $\left.P<0.01\right)$ was highest among the traits studied. Result: Heart girth was found to be most suited among the traits to predict body weight in an exponential equation, $Y=0.00058 H^{p .49}$ and $Y=0.00061 H^{p .47}$ for male and females, respectively, explaining 96 percent of variation.
\end{abstract}

Key words: Body measurement traits, Body weight prediction, Heart girth, Pigs.

\section{INTRODUCTION}

Body measurement traits have widely been used to predict the body weight of farm animals by deriving prediction equation. The method is more commonly used in cattle (El Khidir, 1980; Goe et al., 2001) and to a lesser extent for sheep, pigs and poultry (Lawrence and Fowler, 1997, Singh et al., 2001, Rani et al., 2016, Kumar et al., 2018). Growth is a complex biological process that is induced by differential development rates of body tissues. In practice, external measurements of the body have been used to estimate the development of the skeleton and/or soft tissues of the body (Atta and El Khidir, 2004). According to Sulieman et al. (1990), body length is the distance between scapula and pin bones, while Sandford et al. (1982) described it as the distance between tip of scapula and ischium. Sulieman et al. (1990) reported that body length and height at wither were skeletal measurements that were less variable compared to body weight while considering knee and hock heights as early maturing dimensions. Lawrence and Fowler (1997) observed that the coefficient of determination of multiple regression of heart girth and any other linear measurement on body weight was slightly higher than that of the simple regression of heart girth on body weight. Further, the relationship between heart girth and live weight has been reported to be curvilinear in animals growing over a wide weight range (Lawrence and Fowler, 1997).

In present study, the reliability of different body measurement traits, namely heart girth, punch girth, height at shoulder, height at back, height at fore leg, height at back leg and body length was evaluated for prediction of live weight of pig.

\section{MATERIALS AND METHODS Description of the study area}

The present study was carried out using records of 394 Rani
ICAR-National Research Centre on Pig, Guwahati-781 131, Assam, India.

Corresponding Author: Santanu Banik, ICAR-National Research Centre on Pig, Guwahati-781 131, Assam, India.

Email: santanubanik2000@yahoo.com

How to cite this article: Banik, S., Naskar, S., Barman, K., Das, P.J., Kumar, S. and Rajkhowa, S. (2021). Nonlinear Prediction Models for Estimation of Pre-weaning Body Weight of Pigs using Morphometric Traits. Indian Journal of Animal Research. 55(11): 1383-1386. DOI: 10.18805/IJAR.B-4174.

Submitted: $12-05-2020 \quad$ Accepted: $11-11-2020$

Online: $29-12-2020$

crossbred pigs (Hampshire $\times$ Ghungroo) maintained at nucleus pig breeding farm of ICAR-National Research Centre on Pig, Guwahati (latitude $26.01^{\circ} \mathrm{N}$ and longitude $91.34^{\circ} \mathrm{E} ; 56 \mathrm{~m}$ above MSL), located in north-eastern part of India. Pig farming is one of the major livelihood sources of socio-economically poor farmers of this region. Though north-eastern part of India hosts more than 64 per cent pig population available in the country $\left(20^{\text {th }}\right.$ Livestock Census Report, 2019), still there is a wide deficit between demand and supply of pork for this region in particular and country as a whole, to the tune of 45.45 per cent (Vision 2030, 2011).

\section{Animals}

Looking to the demand-supply gap, mainly due to low production base characterized by low-producing indigenous pig; a crossbreeding programme was initiated at ICARNational Research Centre on Pig, Guwahati by using Ghungroo pigs as indigenous and Hampshire as exotic breed with the objective to develop a suitable variety adapted to local climatic condition with better productive and reproductive performance. The developed Rani crossbred pigs were evaluated for their performance both at organized farm as well as subsistence low-input production system as farmers' field. A prediction equation for body weight 
based on body measurement might be useful for early selection of piglets.

\section{Managemental practice}

Piglets were housed with their dam in indoor pens $(12.0 \mathrm{ft} \mathrm{X}$ $10.0 \mathrm{ft}$ with concrete flooring) varying from 6 to 10 piglets per pen. Water was made available ad lib at all times. Starter ration (maize $55.0 \%$, deoiled ground nut cake $21.0 \%$, soybean meal $17.0 \%$, wheat bran $5.5 \%$, mineral mixture $1.0 \%$ and salt $0.5 \%$; ME $13.78 \mathrm{MJ} / \mathrm{kg}$ diet and CP $24 \%$ ) of $20 \mathrm{~g}$ per animal were offered from third week onward till weaning as per NRC recommendation (NRC, 1998). The amount of ration was gradually increased by $20 \mathrm{~g} /$ week till it reached $80 \mathrm{~g} /$ piglet/d at the time of weaning (wk 6). Veterinary care including deworming and vaccination against swine fever and FMD was routinely offered. The piglets were individually marked by tag for identification.

\section{Measurements}

The records of 394 piglets comprising of 218 male and 176 female, maintained at the farm during 2017-2019, were used for heart girth (circumference around barrel behind fore legs), pounch girth (circumference around barrel before hind legs), height at shoulder (ground to point of shoulder), height at back (ground to point of pin bone), height at fore leg (ground to barrel at fore leg), height at hind leg (ground to barrel at hind leg) and body length (point of wither to starting point of tail) (Banik et al., 2012; Machebe et al. 2016). Weight (kg) and other body measurement traits $(\mathrm{cm})$ of all the animals were recorded on birth, at $15 \mathrm{~d}, 30 \mathrm{~d}$ and $42 \mathrm{~d}$ (weaning). Thus a total of 872 and 704 observation was used to calculate the prediction equation in male and female, respectively.

\section{Statistical analysis}

A least square model (Harvey, 1987) incorporating age of animal and sex was used to estimate their effect on preweaning body weight of pigs. Pooled data over the age was used to predict body weight based on $Y=a X^{b}$, where $Y$ is body weight, $X$ is body measurement, $a$ is constant and $b$ is regression coefficient (Brody, 1945; Lawrence and Fowler, 1997; Atta and El khidir, 2004). The Pearson correlation coefficients $(r)$ for body weight with other body measurement traits were also estimated. The data was analyzed using Statistical Package for the Social Sciences for Windows Version 16.0 (SPSS Inc; Chicago, IL, USA).

\section{RESULTS AND DISCUSSION}

The relationship of body weight with heart girth (0.968), pounch girth (0.933), height at shoulder (0.884), height at back (0.914), height at fore leg (0.946), height at hind leg (0.955) and body length (0.946) were high and highly significant in male piglets. Corresponding estimates in the female piglets were $0.969,0.937,0.909,0.922,0.951$, 0.959 and 0.951 , respectively. The following equations represent non-linear regression of body weight on different parameters.

\section{For male piglets}

$Y=0.00058 H^{2.49} ; r^{2}$ value $=0.96$

$Y=0.00334 P^{2.11} ; r^{2}$ value $=0.87$

$Y=0.02073 S^{1.65} ; r^{2}$ value $=0.72$

$Y=0.00288 B^{2.25} ; r^{2}$ value $=0.81$

$Y=0.00747 F^{2.25} ; r^{2}$ value $=0.87$

$Y=0.00598 L^{2.30} ; r^{2}$ value $=0.88$

$Y=0.00045 B L^{2.55 ;} r^{2}$ value $=0.92$

\section{For female piglets}

$Y=0.00061 H^{2.47} ; r^{2}$ value $=0.96$

$Y=0.00307 P^{2.13} ; r^{2}$ value $=0.88$

$Y=0.01260 S^{1.81} ; r^{2}$ value $=0.77$

$Y=0.00269 B^{2.28} ; r^{2}$ value $=0.82$

$Y=0.00678 F^{2.28} ; r^{2}$ value $=0.88$

$Y=0.00621 L^{2.28} ; r^{2}$ value $=0.89$

$Y=0.00046 B L^{2.54 ;} r^{2}$ value $=0.93$

Where,

$Y$ is the body weight $(\mathrm{kg})$ and $H, P, S, B, F, L, B L$ are heart girth, punch girth, height at shoulder, height at back, height at fore leg, height at back leg and body length $(\mathrm{cm})$, respectively.

The $r^{2}$-values of non-linear equations of body weight with different parameters varied from 0.72 to 0.96 and 0.77 to 0.96 in male and female piglets, respectively. It was found that heart girth is most suited among studied body measurement traits to predict the body weight in an exponential equation explaining $96 \%$ of variation in dependent trait both for male and female piglets. It was followed by body length, height at back leg, height at fore leg, punch girth, height at back and height at shoulder. Perusal of body weight and body measurements traits of different age groups and sex are presented in Table 1. Sex of the animals did not show any significant effect on body weight or other body measurement traits within same age group. However, age group had significant effect $(P<0.01)$ on body weight and body measurement traits.

Heart girth, punch girth, height at shoulder, height at back, height at fore leg, height at back leg and body length were used to predict body weight based on equation, $Y=a X^{b}$ (Brody, 1945; Lawrence and Fowler, 1997). Our observation that prediction of body weight based on heart girth increased coefficient of determination is supported by earlier reports of Johanson and Hildman (1954), Critin et al. (1959), El Khidir (1980) and Atta and El khidir, (2004). Further, skeletal measurements like body length is reported to be less indicative variable for prediction of body weight as compared to heart girth (Lawrence and Fowler, 1997). The change of body weight was equal to the heart girth raised to exponential of 2.49 and 2.47 for males and females, respectively. These findings are in agreement with Brody (1945) and Atta and El Khidir (2004) who found similar type of exponential values while predicting body weight based on heart girth in cattle and sheep, respectively. Body length was second best among traits studied to predict the body weight. It might be more relevant since live weight of lighter animals are estimated more accurately than heavy animals (Johanson and Hildman, 1954). 
It is concluded that heart girth $(H)$ can be used with greater accuracy to estimate live weight $(Y)$ of piglets based on equations, $Y=0.00058 H^{p .49}$ and $Y=0.00061 H^{p .47}$ for male and female pigs, respectively.

Table 1: Body weight and body measurement traits (mean \pm SEM) at different stages of pre-weaned pigs.

\begin{tabular}{|c|c|c|}
\hline & $\begin{array}{l}\text { Male piglets } \\
\quad(\mathrm{N}=218)\end{array}$ & $\begin{array}{l}\text { Female piglets } \\
\qquad(N=176)\end{array}$ \\
\hline \multicolumn{3}{|c|}{ Body weight (cm) } \\
\hline At birth & $1.12^{\mathrm{a}} \pm 0.02$ & $1.10^{\mathrm{a}} \pm 0.03$ \\
\hline At 15 days & $3.56^{b} \pm 0.05$ & $3.45^{b} \pm 0.06$ \\
\hline At 30 days & $5.76^{c} \pm 0.06$ & $5.71^{c} \pm 0.07$ \\
\hline At weaning & $7.28^{d} \pm 0.07$ & $7.37^{d} \pm 0.07$ \\
\hline \multicolumn{3}{|c|}{ Heart girth $(\mathrm{cm})$} \\
\hline At birth & $21.67^{a} \pm 0.17$ & $21.48^{a} \pm 0.21$ \\
\hline At 15 days & $34.08^{\mathrm{b}} \pm 0.37$ & $33.66^{b} \pm 0.44$ \\
\hline At 30 days & $39 . .^{75 b c} \pm 0.22$ & $39.87^{c} \pm 0.30$ \\
\hline At weaning & $43.62^{c} \pm 0.20$ & $43.89^{c} \pm 0.22$ \\
\hline \multicolumn{3}{|c|}{ Punch girth (cm) } \\
\hline At birth & $17.43^{a} \pm 0.15$ & $17.27^{a} \pm 0.18$ \\
\hline At 15 days & $29.25^{b} \pm 0.35$ & $28.75^{\mathrm{b}} \pm 0.41$ \\
\hline At 30 days & $33.34^{c} \pm 0.23$ & $33.19^{c} \pm 0.26$ \\
\hline At weaning & $37.04^{c} \pm 0.30$ & $36.89^{c} \pm 0.35$ \\
\hline \multicolumn{3}{|c|}{ Height at shoulder (cm) } \\
\hline At birth & $17.36^{\mathrm{a}} \pm 0.19$ & $17.02^{\mathrm{a}} \pm 0.19$ \\
\hline At 15 days & $23.39^{b} \pm 0.13$ & $23.14^{b} \pm 0.15$ \\
\hline At 30 days & $27.90^{\mathrm{bc}} \pm 0.15$ & $27.73^{b c} \pm 0.17$ \\
\hline At weaning & $33.26^{c} \pm 0.37$ & $32.41^{c} \pm 0.35$ \\
\hline \multicolumn{3}{|c|}{ Height at back $(\mathrm{cm})$} \\
\hline At birth & $17.61^{a} \pm 0.20$ & $17.34^{\mathrm{a}} \pm 0.20$ \\
\hline At 15 days & $23.92^{\mathrm{b}} \pm 0.14$ & $23.58^{\mathrm{b}} \pm 0.15$ \\
\hline At 30 days & $27.62^{\mathrm{bc}} \pm 0.19$ & $27.32^{\mathrm{bc}} \pm 0.21$ \\
\hline At weaning & $32.27^{\mathrm{c}} \pm 0.13$ & $32.17^{c} \pm 0.14$ \\
\hline \multicolumn{3}{|c|}{ Height at fore leg $(\mathrm{cm})$} \\
\hline At birth & $11.44^{\mathrm{a}} \pm 0.08$ & $11.33^{\mathrm{a}} \pm 0.10$ \\
\hline At 15 days & $15.65^{b} \pm 0.13$ & $15.44^{b} \pm 0.16$ \\
\hline At 30 days & $19.00^{c} \pm 0.14$ & $18.87^{c} \pm 0.15$ \\
\hline At 45 days & $20.55^{c} \pm 0.18$ & $20.69^{c} \pm 0.20$ \\
\hline \multicolumn{3}{|c|}{ Height at back leg $(\mathrm{cm})$} \\
\hline At birth & $12.19^{\mathrm{a}} \pm 0.09$ & $12.07^{a} \pm 0.10$ \\
\hline At 15 days & $16.13^{b} \pm 0.13$ & $15.79^{\mathrm{b}} \pm 0.15$ \\
\hline At 30 days & $19.59^{c} \pm 0.11$ & $19.57^{c} \pm 0.13$ \\
\hline At weaning & $21.52^{\mathrm{c}} \pm 0.20$ & $21.71^{c} \pm 0.21$ \\
\hline \multicolumn{3}{|c|}{ Body length (cm) } \\
\hline At birth & $21.24^{\mathrm{a}} \pm 0.21$ & $21.00^{a} \pm 0.23$ \\
\hline At 15 days & $34.26^{b} \pm 0.39$ & $33.96^{b} \pm 0.43$ \\
\hline At 30 days & $40.76^{c} \pm 0.16$ & $40.71^{c} \pm 0.25$ \\
\hline At weaning & $43.62^{c} \pm 0.19$ & $43.94^{c} \pm 0.19$ \\
\hline
\end{tabular}

Means with different superscripts within same column differ significantly $(\mathrm{P}<0.01)$.

\section{CONCLUSION}

It is recommended that, correlation of heart girth with body weight $\left(r^{2}=0.968\right.$ for male and 0.969 for females; $\left.\mathrm{P}<0.01\right)$ was highest among the traits studied. Heart girth was found to be most suited among the traits to predict body weight in an exponential equation, $Y=0.00058 H^{2.49}$ and $Y=0.00061$ $H^{2.47}$ for male and females, respectively, explaining 96 percent of variation.

\section{ACKNOWLEDGEMENT}

Authors are thankful to Indian Council of Agricultural Research, New Delhi and Director, National Research Centre on Pig, Guwahati for providing funds and facilities for this study.

\section{Compliance with ethical standards Conflict of interest}

No conflict of interest exists.

\section{REFERENCES}

$20^{\text {th }}$ Livestock Census All India Report (2019). DAHD and F, Ministry of Animal Husbandry, Dairying and Fisheries, Ministry of Agriculture, Government of India.

Atta, M. and El-Khidir, O.A. (2004). Use of heart girth, wither height and scapuloischial length for prediction of liveweight of Nilotic sheep. Small Ruminant Research. 55: 233-237.

Banik, S., Naskar, S., Pankaj, P.K., Sahoo, N.R., Tamuli, M.K. and Das, A. (2012). Effect of different body measurement on body weight of pre-weaning Ghungroo pigs - A path analysis approach. Indian Journal of Animal Sciences. 82: 1094-1097.

Brody, S. (1945). Bioenergetics and Growth. Reinhold, New York, USA.

Critin, J.A., Aitken, J.N. and Boyre, A.W. (1959). The effect of plane of nutrition during rearing on growth, production, reproduction and health of dairy cattle. 1. Growth to 24 months. Animal Production. 1: 145-162.

El Khidir, O.A. (1980). A note on prediction of liveweight of growing Kenana heifers from linear body measurements. Sudan Journal of Veterinary Science and Animal Husbandry. 21: 102-104.

Goe, M.R., Alldredge, J.R. and Light, D. (2001). Use of heart girth to predict body weight of working oxen in the Ethiopian highlands. Livestock Production Science. 69: 187-195.

Harvey, W.R. (1987). Least squares analysis of data with unequal subclass numbers. ARS H-4, USDA, Washington D.C.

Johanson, I. and Hildman, S.E. (1954). The relationship between certain body measurement and live and slaughter weights in cattle. Animal Breeding Abstract. 22: 1-17.

Kumar, S., Dhita, S.P., Malik, Z.S. and Patil, C.S. (2018). Prediction of body weight from linear body measurements in sheep. Indian Journal of Animal Research. 52(9): 1263-1266.

Lawrence, T.L. and Fowler, V.R. (1997). Growth of Farm Animals. CAB International, Wallingford, Oxon, UK. 
Machebe, N.S., Ezekwe, A.G., Okeke, G.C. and Banik, S. (2016) Path analysis of body weight in grower and finisher pigs. Indian Journal of Animal Research. 50(5): 794-798.

NRC. (1998). Nutrient Requirement of Swine. National Academy Press, Washington DC.

Rani, M., Ekambaram, B. and Kumari, P. (2016). Prediction of body weights of Nellore sheep under field condition. Indian Journal of Animal Research. 50(1): 133-136.

Sandford, J., Wissocq, Y.J., Durkin, J. and Trail, J.C.M. (1982). Evaluation of productivities of Djallonke sheep and N'dama cattle at the Center de Recherches Zootechniques, Kolda, Senegal. ILCA Research Report. 3: 9-39.
Singh, S.K., Pandey, R.N. and Sharma, B.D. (2001). Prediction of body weight from linear body measurements in pigs. Indian Journal of Animal Research. 35(1): 15-20.

Statistical Package for the Social Sciences (SPSS) Inc. Chicago, IL, USA.

Sulieman, A.H., Sayers, A.R. and Wilson, R.T. (1990). Evaluation of Shugar, Dubasi and Watish subecotypes of Sudan desert sheep at El Huda National Sheep Research Station, Gezira Province, Sudan. ILCA Research Report. 18: 30. Vision 2030 (2011). ICAR-National Research Centre on Pig, Guwahati, India. 